\title{
Service Sector: Rationale of Substance of Investment Potential and Methods of Its Determining
}

\author{
Yerokhina Lidiya Ivanovna
}

Volga Region State University of Service, 4 Gagarina street, Tolyatti, 445677, Samara Region

\section{Doi:10.5901/mjss.2015.v6n3s2p661}

\begin{abstract}
The article is dedicated to research of the problem of assessment of investment opportunities and investment potential of the service sector. Based on a study of existing approaches and methods there were distinguished two groups in the method of determining of investment potential and the status of economic development of the service sector which are assessment of the service sector investment potential and assessment of the service sector investment activity. Each group consists of the following modules: a list of questions arising in connection with performance of an investment process in the service sector; a system of indices characterizing the status of the service sector in the certain sphere; a set of criteria compulsory for the service sector in the certain sphere.
\end{abstract}

Keywords: service sector, investment activity, investment potential, investment opportunities.

\section{Introduction}

The current economy of Russia as well as the economies of developed countries is characterized by the processes of deindustrialization, during which the service sector obtains a greater influence on the level and quality of life and begins to occupy a leading position in production of the gross national product of the country (Materov, 2003). The uniqueness of the situation in Russia is determined by the fact that development of the service sector depends not only on the impact of global trends but also on the rapidly changing socioeconomic relations in the country (Bayramukova \& Voskanov, 2012).

In this regard the study of all aspects of the service sector development, its trends, forms, qualitative and quantitative characteristics is not only relevant from a scientific perspective but also has direct practical importance from a perspective to find the most optimal ways of further Russian economy restructuring.

Change of the role, place and importance of the service sector which has become dominant and defining as a part of post-industrial economic systems has a significant impact on the content of the modern market economy. Hence the need for new approaches to the explanation of economic and theoretical aspects of the service sector and first of all rationalization of substance of the service sector investment potential within the process of social reproduction in modern Russia under the market economy conditions assumes significance.

\section{Methodology}

Allocation of investment activities as an independent sphere, comparable in complexity and importance to other activities, results in change of the system of management, organization and financing of investment activity in the service sector. For businesses in the services sector it is becoming one of the most important areas of work which affects there functioning in the present and future (Grigor'ev, 2008).

Study of the problem of evaluation of the service sector investment opportunities shows that at the present time there are quite a number of different techniques that allow determining investment opportunities and investment attractiveness of business entities to a greater or lesser extent.

Many researchers evaluate investment opportunities and general economic condition of business entities based on the principle of limiting factors and are satisfied with use of financial indicators only (Melkumov,1997; Higle \& Corrado 1992). We do not consider this approach to be justifiable enough because it narrows the assessment basis of the research and is unlikely to contribute to adoption of the relevant investment decisions.

In recent years there has been a tendency to increase the number of indicators that provide a more complete idea of economic potential and investment opportunities of a business entity. For example it is worth to mention a classification of productive system factors by Buchulayev A.M. which includes organizational and managerial, material and technical as 
well as social and labor factors (Buchulayev, 2001). Another researcher Tuzov N.E. distinguished such investment planning factors as organizational and production, financial and economical as well as social and labor ones (Tuzov,2002). Stepanova O.A. has an opinion similar to the above mentioned nevertheless at time of estimating economic resilience of an enterprise she takes into account a production, investment, financial and organizational strategy (Stepanova, 2002).

Analysis of the existing methods shows that an enterprise or a group of enterprises are more frequently used as an object of research, and an industry or an economy sector serves less frequently in this capacity. In recent years national statistics began to pay more serious attention to the problems of investment in various sectors of the economy (Solovieva \& Telyatnikova,2012). To this effect data collection and processing are being performed for definite sectors; analysis of such data ultimately allows determining investment potential and investment activity in these sectors. Pursuit of investment opportunities evaluation is quite clear and is equally important for both an investor and a recipient. An investment process must necessarily be profitable for an investor, so he must be aware about the status of investment opportunities of an industry (Grigor'ev, 2008). On the other hand such factors as the size of capital investments (both domestic and foreign) and their frequency, i.e. factors ensuring conditions for the sector development, its renovation, modernization, technical re-equipment, growth and maintenance of competitive ability have significance for a recipient. For this aim a recipient should have clear understanding of its own abilities and level of preparedness for an investment process implementation, as well as of the size of financial investments on which he can rely.

Official statistical survey involves more than thirty indicators that are joined into several groups and give an idea of the status of the resource, industrial, labor, financial and institutional capacities, as well as of the degree of investment activity and investment performance of an industry.

Without prejudice to the importance of the above methods and approaches we offer to extend the areas of investment activity analysis and evaluation of investment opportunities for an investment process implementation in the service sector. The method offered by us uses expansion approach to the definition of investment potential of the service sector allowing to keep homeostasis of the industry and ensuring its investment attractiveness as well as the basis for economic growth within the same. In addition we believe that the characteristic features of the service sector investment potential determine the type of economic growth within the same and its specificity.

In connection with the above we've divided the method for determining the investment potential and the status of economic development of the service sector into two directions (groups):

1. group - assessment of the service sector investment potential;

2. group - assessment of the service sector investment activity.

There are several modules within each of the groups:

- a list of questions which arise in connection with performance of an investment process and which are applied to the service sector;

- $\quad$ system of indices characterizing the status of the service sector in the certain sphere;

- a set of criteria compulsory for the service sector in the certain sphere.

The method has adopted a "conventional reference service sector" as a basis of comparison.

Besides we offer to perform comparison of the service sector indices according to the following aspects:

1. comparison with the general level of the Central Federal District (except for Moscow city);

2. comparison with the general regional level;

3. comparison with individual entities within the CFD;

4. comparison of individual industries with the regional service sector;

5. comparison with the rated values.

The technique developed by us is based on use of the methods of explication, decomposition, composition, ranking score, expert survey and other.

\section{Main Part}

We offer to perform analysis of the service sector investment potential and its assessment (1 group) with involvement of the expansion approach according to the following directions: resources provision; labor potential; production potential; institutional features; financial status; credit reputation of the service sector; innovative potential; information support; market factor (consumption potential); infrastructural potential.

Hence we offer to analyze the following indices in order to assess the investment potential (Table. 1). 
Table 1. The system of indices for assessment of the service sector investment potential

\begin{tabular}{|c|c|}
\hline Assessment direction & A set of indices \\
\hline Resources provision & $\begin{array}{l}\text { - volume of fixed assets and their dynamics; } \\
\text { - depreciation of fixed assets and in particular of their active part; } \\
\text { - coefficient of renewal and coefficient of disposal of fixed assets and their elements; } \\
\text { - share of material costs in the volume of total costs of production and sales of services, inclusive } \\
\text { of raw materials and supplies, fuel and energy; }\end{array}$ \\
\hline Labor potential & $\begin{array}{l}\text { - } \text { average annual number of personnel in the service sector; } \\
\text { - personnel circulation: engaged - discharged; } \\
\text { — share of high-qualified personnel; } \\
\text { - share of personnel working under disadvantageous labor conditions; } \\
\text { - } \text { average actual length of working-day; } \\
\text { - } \text { average monthly accrued wages of the service sector personnel; } \\
\text { - overdue wages indebtedness to personnel (as of the end of period); } \\
\text { - capital-labor ratio; } \\
\text { - labor efficiency. }\end{array}$ \\
\hline Production potential & $\begin{array}{l}\text { - volume of sales of services and dynamics of its change; } \\
\text { - share of volume of services sales in gross domestic product (gross regional product); } \\
\text { - services producer price index as of the end of period; } \\
\text { - capital productivity; } \\
\text { - level of accumulation; } \\
\text { - services sales profitability. }\end{array}$ \\
\hline Institutional features & $\begin{array}{l}\text { - total number of enterprises in the service sector and their dynamics; } \\
\text { - number of small enterprises in the service sector; } \\
\text { - structure of enterprises by pattern of ownership; } \\
\text { - structure of enterprises by size; } \\
\text { - number of business entities having market share exceeding } 35 \% ; \\
\text { - coefficient of establishment and official liquidation of enterprises. }\end{array}$ \\
\hline Financial status & $\begin{array}{l}\text { - ratio of profitable and unprofitable enterprises; } \\
\text { — } \text { ratio of receivables and payables; } \\
\text { - value of overdue indebtedness and its structure; } \\
\text { - amount of profit and damages; } \\
\text { - indicators of financial soundness: current ratio, working capital to current assets ratio, equity to } \\
\text { total assets ratio; } \\
\text { - number of enterprises in default in the service sphere. }\end{array}$ \\
\hline $\begin{array}{l}\text { Credit reputation of the } \\
\text { service sector }\end{array}$ & $\begin{array}{l}\text { - value of loans and credits; } \\
\text { - value of overdue loans and credits; } \\
\text { - business solvency ranking score of the service sector. }\end{array}$ \\
\hline Innovative potential & $\begin{array}{l}\text { - amount of innovative work in the service sector; } \\
\text { - share of investment in innovation; } \\
\text { - share of investment in science; } \\
\text { - number of enterprises in the service sector producing innovative products; } \\
\text { - novelty of researches in the service sector. }\end{array}$ \\
\hline Information support & $\begin{array}{l}\text { - degree of elaboration of a legislative and regulatory framework of investment activity in the } \\
\text { service sector; } \\
\text { - degree of elaboration of guidance materials regulating assessment of investment projects in the } \\
\text { service sector; } \\
\text { - degree of elaboration of a system of standards in the service sector; } \\
\text { - availability of special units dealing with development of a strategy and tactics of an investment } \\
\text { project in the service sector. }\end{array}$ \\
\hline Market potential & $\begin{array}{l}\text { - actual volume of services sales; } \\
\text { - share of products produced in the service sector in the retail turnover volume. }\end{array}$ \\
\hline Infrastructural potential & $\begin{array}{l}\text { - compliance of the service sector infrastructure with the requirements to consistency of an } \\
\text { investment process and economic growth; } \\
\text { - status of allied and linked industries supplying raw and other materials, equipment, personnel, } \\
\text { new technologies and other economic resources to the service sector. }\end{array}$ \\
\hline
\end{tabular}

So based on the above stated the current status of investment potential of the service sector may be presented as a 
functional relation of a system of components, i.e.:

Innp $=f(R P, L P, P P, I F, F S, C R, \operatorname{In} P, \operatorname{Inf} S, M P, \operatorname{Infr} P)$,

where $R P$ - resources provision in the service sector;

$L P$ - labor potential of the service sector;

$P P$ - production potential of the service sector;

IF - institutional features of the service sector;

FS - financial status of the service sector;

$C R$ - credit reputation of the service sector;

InP - innovative potential of the service sector;

InfS - information support of the service sector;

MP- market potential of the service sector;

InfrP - infrastructural potential of the service sector.

However the process of the service sector functioning is not strictly formalized, moreover it does not seem possible to give a formalized and explicit description of assessment of the current investment potential of the service sector. In such cases modeling is based on decomposition of the process under investigation into individual components, their analysis and assessment as well as finding out system interrelations which will be later used for composition of the expected results. In view of this the service sector investment potential may be presented as a system of indices which characterize the said components. As practice shows, in management decisions, including those investment-related the managers tend to satisfactory or more precisely named as "satisfying" rather then to "maximizing" behavior. Therefore we assume that in practice the proposed number of indices and components of investment potential would be reduced.

Investment activity of the service sector (group 2) is defined by the investment process status. Both an investor and a recipient evaluate investment activity from the point of view of structural charges in an investment process in the services sector, growth or decrease of the real investments volume. Analysis of the state of an investment process in the service sector for a five-year period or more long period allows to figure out an actual image of the changes in the investment service sector, to discover problems and trends as well as to plan future development.

Evaluation of an investment process in the service sector may be performed with use of a whole range of indices. The most significant directions of assessment of investment activity in the service sector are as follows:

- volume of investments to fixed capital and their dynamics;

- technological structure of investments;

- $\quad$ reproductive structure of investments;

- proportion of fixed capital investments by patterns of ownership;

- structure of investments depending on the financing sources;

- share of foreign investments in the service sector.

\section{Findings}

Thus taking into account generalizations of existing theoretical and methodological scientific knowledge we've developed the methods of determining the service sector investment potential and the state of economic development.

\section{Conclusions}

The service sector investment potential determines its attractiveness and creates opportunities for its economic growth (Asambaev, 2002). It is not quite appropriate to evaluate the service sector investment potential from the point of view of limiting factors, in particular financial resources. We share the position of those investigators who use the expansive approach to the investment potential and take into account saturation of the service sector with various factors (resources, labor power, capital assets, infrastructure, etc.). In accordance with this approach, the service sector investment potential is an aggregation of resource, manufacturing, financial, institutional, consumer, infrastructure, information and labor potentials. Such vision of the definition of investment potential will give an opportunity of comprehensive economic development of the service sector directions.

\section{References}

Asambaev, N.N. (2002). Investment in Russia, 3, 10-16.

Buchulayev, A. M. (2001). Evaluating the effectiveness of performance management in the regional construction sectors. PhD thesis 
(Economy). (pp. 14-15).

Bayramukova, F.A., Voskanov, M.E. (2012). Place and role of a service sector institute in development of regional socioeconomic systems. Bulleting of the Institute of the Caucasus Peoples' Friendship "Theory of economy and management of the national economy", 4(24), 115-121

Grigor'ev, L. (2008). Economic issues, 4, 12-18.(нет названия статьи)

Grigor'ev, L. (2008). Investment process: accumulated problems and interests. Voprosy Economiki, 4, 44-61.

Higle, J.L., \& Corrado, C.J. (1992). Economic Investment Times for Capacity Expansion Problems. European Journal of Operational Research, 59, 2, 288-293.

Materov, I. (2003). Factors of development of "new economy" in Russia. The Economist, 2, 3-11.

Melkumov, Y. S. (1997). Economic assessment of efficiency of investments and investment projects financing. Moscow: Publishing and Consultation Center "Delo i Servis".

Stepanova, O.A. (2002). Procedure of estimating economic resilience of construction enterprises. PhD thesis (Economy). (pp. 14-19).

Solovieva, N.S., \& Telyatnikova, V.S. (2012). Investment potential of industrial complex region's development. Problems and trends of economy and management in the modern world. Proceedings of the International Conference. (pp. 568-576).

Tuzov, N.Y. (2002). Scientific base of diagnostics of economic state of construction enterprises in competitive environment (as exemplified by the construction industry enterprises). $\mathrm{PhD}$ thesis (Economy). (pp. 13-14). 